\title{
Descriptive Content Analysis on E-Service Research
}

Jung-Hwan Kim, Department of Retailing, College of Hospitality, Retail and Sport Management, University of South Carolina, Columbia, SC, USA

Sharron J. Lennon, Department of Apparel Merchandising and Interior Design, Indiana University, Bloomington, IN, USA

\begin{abstract}
The current study systematically and thoroughly reviewed the extant literature on e-service quality research to examine 1) how e-service is defined by researchers, 2) how e-service quality is defined by researchers, 3) what e-service quality scales and dimensions have been identified, 4) what outcome variables have been assessed in the e-service quality literature, and 5) what theories have been applied in the literature. A total of 72 articles published between 2003 and 2013 were content analyzed. The selected articles focused primarily on e-service quality in the context of B2C e-retailing. The findings of the study provide valuable information to e-service researchers by identifying gaps and disparities in the e-service quality literature. This study provides several crucial suggestions and directions for future research.
\end{abstract}

\section{KEYWORDS}

Content Analysis, Dimensions, E-commerce, Scales, Service, Service Quality, Theory

\section{INTRODUCTION}

Electronic commerce (e-commerce) emerged in the mid-1990s (Toufaily, Ricard, \& Perrien, 2013). Over the last 20 years, with the rapid advent of the Internet and e-commerce and as more and more people become involved with online shopping, a growing number of research studies focused on e-service quality. Researchers developed various scales and dimensions to measure key elements of e-service quality. However, those e-service research studies oftentimes either did not provide a clear definition of e-service quality or the definition provided was unclear and ambiguous. Key dimensions of e-service quality were also frequently inconsistent across studies (Kim \& Lennon, 2012; Ladhari, 2010; Yaya, Marimon, \& Fa, 2012).

The concept of service quality is one of the most significant research topics in marketing because of its relation to financial performance, customer satisfaction, customer loyalty, and customer reassurance (Zahedifard, Mohebi, \& Dastrain, 2014). Due to its importance e-service quality is one of the most investigated research topics in the context of e-commerce, and many researchers have identified new dimensions and developed new scales as a means of assessing e-service quality. In spite of these efforts, Akinci, Atilgan-Ina, and Aksoy (2010) pointed out that research on e-service quality is at a preliminary phase compared to the traditional service quality literature. There is little research conducted specifically to provide a systematic review of the extant research that provides a holistic overview of current e-service research and provides direction to the e-service quality literature. Without a holistic and comprehensive review of previous research on e-service quality to identify gaps and disparities in the literature, e-service quality research will not advance beyond the preliminary phase. 
Recently in an attempt to address this issue, Kim and Lennon (2012) reviewed extant research articles on e-service quality to define e-service and to review dimensions of e-service quality. However, their research did not comprehensively content analyze the reviewed articles and did not conduct a systematic search to locate empirical research for analysis.

To address this limitation, the current study systematically and thoroughly content analyzed the extant literature on e-service quality research published during a 11 year period (January 2003 to December 2013) to examine 1) how e-service is defined by researchers, 2) how e-service quality is defined by researchers, 3) what e-service quality scales and dimensions have been identified, 4) what outcome variables have been assessed in the e-service quality literature, and 5) what theories have been applied in the literature. Content analysis is a widely used qualitative research method (Hsieh $\&$ Shannon, 2005) used in various fields to analyze text data (Cavanagh, 1997). It is an unobtrusive and nonreactive approach to provide knowledge and understand phenomena of interest (Hsieh \& Shannon, 2005). Using content analysis, researchers can systematically and objectively understand a phenomenon by describing and quantifying it (Elo \& Kyngäs, 2007).

\section{THEORETICAL /CONCEPTUAL BACKGROUND AND DEVELOPMENT OF RESEARCH QUESTIONS}

\section{Theoretical Background of Service Quality}

The service quality model proposed by Grönroos (1984) is the first theory developed in the field of service quality (Polyakova \& Mirza, 2015). Grönroos's service quality model was developed to understand the components of service quality and how the quality of services is perceived by consumers (Grönroos, 1984).

In this model, consumers' expectations towards a firm's service and their actual perceptions of the service are the two components of service quality. A firm's promises to consumers and the consumers' previous experience affect consumers' expectations for service, while the perceived service is the outcome of the consumers' perceptions of the service itself. There are two dimensions of quality that affect consumers' evaluations of service quality: technical quality (i.e., what services consumers receive) and functional quality (i.e., how consumers receive services). The model puts more emphasis on functional quality than on technical quality in affecting consumers' perceived service quality. In keeping with this note, in an empirical study by Zaibaf, Taherikia, and Fakharian (2013) using Grönroos service quality model in an offline retail environment, no significant relationship between technical quality and perceived quality was found.

In the context of e-retailing where the interaction is only between human and a machine, how a consumer interacts with a retailing site to get a desired product (i.e., functional quality) is particularly important. Thus, based on the emphasized relationship between functional quality and perceived service in Grönroos' service quality model, the current study conducted a content analysis of e-service quality research to thoroughly understand the antecedents and consequences of e-service quality. Definitions of e-service, e-service quality, and theories employed were also examined.

\section{E-Service}

Service quality is an indispensable component in today's highly competitive business. It affects almost all aspects of consumer behavior such as customer's value, trust, commitment, long term customer loyalty (Thaichon, Lobo, Prentice, \& Quach, 2014), purchase intention, satisfaction, attitudes toward the website, and perceived risk (Vila \& Kuster, 2011). Rust (2001) defined e-service as "the provision of service over electronic networks" (p. 283). Sanayei, Shaemi, and Nasirzadeh (2011) defined 
e-service as web-based self-service. These definitions are not explicit and quite circular by using the term "service" in the definitions. In a more descriptive way, Rust and Lemon (2001, p. 86) inferred that e-service goes beyond order fulfillment, responsiveness to inquiries, email and status requests. Its primary intent is "to provide consumers with a superior experience with respect to the interactive flow of information" (Rust \& Lemon, 2001, p. 86).

From a more advanced viewpoint, Sabiote, Frías, and Castañeda (2012) defined e-service as "added value above and beyond the exchange of information made possible by the Internet" (p. 158). The definition described in Sabiote et al. (2012) implies a much more wide-ranging view of e-service by addressing supplementary value which extends further beyond the exchange of information through the Internet.

Today an e-commerce website is not a simple functional tool that helps a consumer order products and services. It can evoke pleasure and encourage interaction as well (Bressolles, Durrieu, $\&$ Senecal, 2014). Besides shopping and purchasing, consumers visit e-commerce sites to search for relevant information or to interact with elements of the site for enjoyment. Approximately $81 \%$ of consumers search online before making a purchase (Retailing Today, 2013). According to Charlton (2015), 61\% of customers visit e-commerce sites to see customer reviews before making a purchase decision. Furthermore, today more and more consumers are actively involved with various product development processes by custom-designing product features on retailers' websites. How e-service is defined in the literature is crucial to understand the explicit aspects of e-service. Therefore, the first research question was developed.

RQ1: How is e-service defined in e-service research?

\section{E-Service Quality}

E-service quality is a key element of a firm's competitive advantage and a factor affecting a firm's long term success (Carlson \& O'Cass, 2011). Santos (2003) defined e-service quality as “consumers' overall evaluation and judgment of the excellence and quality of e-service offerings in the virtual market place" (p. 235). This definition is somewhat circular and vague and lacks a clear explanation of what e-service offerings need to be included. Zeithaml, Parasuraman, and Malhotra (2000) defined e-service quality as the extent to which a website facilitates efficient and effective shopping, purchasing, and delivery of products or services. The definition of e-service quality defined by Zeithaml et al. is comprehensive in that it encompasses all website service aspects from pre-purchase stage to post-purchase stage.

According to Santos (2003), consumers perceive the quality of e-service based on the overall process and outcome rather than based on a one-time event of a single visit to a website. Parasuraman et al. (2005) pointed out that consumers' evaluation of web-site quality is driven through the postinteraction service features as well as the experiences during their interactions with the site. This view is somewhat consistent with Wolfinbarger and Gilly's (2003) study which indicated that consumers' online buying experience derives from more than merely a website interface. The online buying experience includes everything from searching for information, evaluation of products, transaction, delivery, returns, and customer service (Rafiq, Lu, \& Fulford, 2011). Service quality is the most investigated area of services marketing (Lin, 2012) and has a significant impact on many crucial aspects of e-commerce (Ladhari, 2010). Hence, it is vital to examine how e-service quality is defined and formulated in the literature. Thus, the second research question was developed:

RQ2: How is e-service quality defined in e-service quality research?

\section{E-service Quality Scales and Dimensions}

As e-commerce has become an essential shopping medium for consumers, many researchers and practitioners have focused on factors that influence e-service quality and have created numerous scales 
measuring various dimensions of e-service quality. For instance, Yoo and Donthu (2001) developed SITEQUAL to gauge website quality of e-retailers. The scale includes four dimensions: ease of use, aesthetic design, processing speed, and security. Wolfinbarger and Gilly (2003) created eTailQ which includes four dimensions: website design, reliability/fulfillment, privacy/security, and customer service. In 2005, Parasuraman et al. proposed e-SQ which includes 4 dimensions of E-S-QUAL (efficiency, system availability, fulfilment, and privacy) and 3 dimensions of E-Rec-QUAL (responsiveness, compensation, and contact). This scale is quite comprehensive but predominantly focuses on utilitarian aspects of e-service quality (Kim, Kim, \& Lennon, 2006). By including both utilitarian and hedonic elements, Bauer, Falk, and Hammerschmidt (2006) proposed eTransQual which includes 5 dimensions (functionality/design, enjoyment, process, reliability, and responsiveness). In recent years, partially because of the absence of ideal scales assessing e-service quality, many researchers have combined or modified dimensions proposed by previous researchers to identify key dimensions of e-service quality (e.g., Poon \& Lee, 2012; Rolland \& Freeman, 2010; Swaid \& Wigand, 2012).

Just as there are numerous dimensions and scales used in the e-service quality literature, the key factors identified in relation to dimensions and scales are various and inconsistent. For instance, in Tsang et al (2010), safety/security was a significant factor that affected overall satisfaction with a site. In Wolfinbarger and Gilly's research (2003), fulfillment/reliability was the strongest factor affecting satisfaction and security/privacy was not a significant factor in affecting overall satisfaction. Considering the lack of commonality among the various scales/dimensions identified, it is important to provide a comprehensive overview of the scales and dimensions in the extant e-service quality literature. Thus, to evaluate what scales have been developed and what dimensions have been investigated and identified, the following research questions were developed:

RQ3a: What e-service quality scales have been developed?

RQ3b: What dimensions of e-service quality have been investigated?

\section{Outcome Variables of E-service Quality}

Compared to various dimensions of e-service quality, only a few outcome variables have been investigated in the e-service quality literature. For instance, Parasuraman et al. (2005) included overall e-service quality, perceived value, and loyalty as outcome variables to examine the effect of E-SQUAL dimensions. Bauer, Falk, and Hammerschmidt (2006) examined key dimensions of e-service quality in association with perceived value and customer satisfaction. Wolfinbarger and Gilly (2003) examined e-service quality in relation to quality, satisfaction, loyalty intention, and attitude towards the site. E-satisfaction seems to be the most studied outcome variable in the e-service quality literature and some outcome variables seem to be duplicated in the literature. To review the outcome variables examined in the extant e-service quality literature and have a clear understanding of the influence of key dimensions of e-service quality on consumer shopping outcomes, the following fourth research question was developed.

RQ4: What outcome variables have been assessed in the e-service quality research?

\section{The Use of Theory in E-service Quality}

Kerlinger (1979) defined a theory as "a set of interrelated constructs (variables), definitions, and propositions that represents a systematic view of phenomena by specifying relations among variables, with the purpose of explaining natural phenomena" (as cited in Creswell, 2014, p. 54). Garrison (2000) defined theory as "a coherent and systematic ordering of ideas, concepts and models, with a purpose of constructing meaning to explain, to interpret, to shape practice" (as cited in Bernath \& Vidal, 2007, p. 431). According to Wacker (1998), some academics believe that theory and its application might be limiting and thus not very useful in the real business world. Others consider that there cannot be 
research without theory (Bernath \& Vidal, 2007). In quantitative research, a theory plays an important role by 1) acting as an underlying basis to explain the central hypothesis or major research questions and 2) explaining the relationship between independent and dependent variables (Creswell, 2014).

In the e-service quality literature, the relationship among key dimensions, overall e-service quality, and outcome variables is often inconsistent across studies. Despite the number of e-service quality studies, no clear relationships among these factors have been established. The lack of clear theoretical foundation in the e-service literature might be a reason that could explain this phenomenon. Therefore, to examine what theories have been applied in the e-service literature, the following research question was developed.

RQ5: What theories have been applied in the e-service research?

\section{METHODS}

\section{Scope of Studies}

The current study content analyzed e-service quality articles appearing in peer-reviewed journals from January 2003 to December 2013 1) to identify diverse definitions of e-service employed in the research, 2) to identify various definitions of e-service quality applied in the research, 3) to describe e-service quality scales and key dimensions of e-service quality, 4) to determine the outcome variables examined in the e-service quality literature, and 5) to identify the theories the authors utilized. Conference proceedings and non-refereed sources such as doctoral dissertations, master's theses, and unpublished research were not included due to the amount and quality of the articles on the whole. This study performed a directed content analysis. Compared to a conventional content analysis in which coding categories are derived directly from the text data, a directed content analysis begins by identifying key concepts or variables as initial coding categories (Hsieh \& Shannon, 2005; Potter \& Levine-Donnerstein, 1999).

\section{Search Procedure}

EBSCOhost electronic database was used to find extant e-service/e-service quality articles. E-service (quality), Internet service (quality), online service (quality), web-site (website, web site) service quality, and service quality were the key terms inserted in the search categories of title, abstract, and keywords. The references cited in the articles were further searched to find any other relevant articles not included in the search. One of the researchers and a trained coder were involved with the extensive and systematic search process. In total, 123 articles were identified. The abstract of each of the 123 articles was carefully reviewed to confirm relevance in relation to the purpose of the study. The confirmation process led to the elimination of 29 articles, leaving 94 articles relevant for the study.

\section{Coding Guide Development and Data Collection}

To prepare a coding form and guidelines, two researchers first identified key variables to include in the initial coding form. The variables included in the coding form were definition of e-service, definition of e-service quality, independent variables, dependent variables, e-service quality scales, e-service quality dimensions, and theory used. With the key variables identified, the two researchers independently reviewed five articles. The two researchers' coding forms were compared and the disagreements were discussed and resolved. After finalizing the coding form, two graduate students were trained by the two researchers as coders and asked to code three articles to compute intercoder reliability. The inter-coder reliability between the coders was calculated using the percentage agreement (total number of agreement was divided by total items coded) and found to be .83 . The parts not in agreement were re-evaluated by the researchers and discussed with the coders until consensus was achieved. The remaining un-coded articles were split among the two coders. During 
the coding process, 22 non-empirical articles were excluded. As a result, a total of 72 articles were identified as relevant for the study.

\section{RESULTS}

The 72 articles were content analyzed for the study. The selected articles focused primarily on e-service quality in the context of B2C e-retailing. The findings of the content analysis are presented, organized by the research questions.

\section{Definition of E-service}

Of the 72 articles examined, only $13(18.1 \%)$ provided a definition of e-service. The definitions available in the literature were largely limited to the interactive activity with the site over the Internet and/or were circular by using the term service in the definition. In many instances, e-service was defined as any interactive service over the Internet $(f=3,23.1 \%)$, interactive information service $(f$ $=3,23.1 \%$ ), or provision of service over the Internet $(f=4,33.3 \%)$. One study simply defined it as web-based self-service. Another article defined it as including processes, policies, procedures, people, tools, and technologies. Yet another study introduced it in connection with customer experience going beyond mere information flow. A few articles expanded the definition by embracing other electronic networks such as mobile devices.

\section{Definition of E-service Quality}

E-service quality was defined in 46 articles (63.9\%). The most frequently mentioned definition was "the extent to which a website facilitates efficient and effective shopping, purchasing and delivery," provided by Zeithaml et al (2002) and Parasuraman et al. (2005) $(f=20,43.5 \%)$. The service quality gap between expectations of service and perceptions of performance of service defined by Parasuraman et al. $(1985,1988)$ was noted in 9 articles $(19.6 \%)$. "Consumers' overall evaluation and judgment of the quality of the e-service delivery in the virtual marketplace" defined by Santos (2003, p. 235) was mentioned in 7 articles (15.2\%). Based on the definition of e-service quality of Zeithaml et al. (2002), Rolland and Freeman provide a more thorough definition by embracing all types of interactions that customers experience from initial contact to fulfillment of the service (i.e., service delivery, customer support, and information provision). Some articles defined e-service quality as consumers' evaluation during their interactions with the site. Others stressed consumers' perceptions of outcome and recovery quality. One article proposed that service quality differs from website design quality and only relates to after-sales service (e.g., on-time delivery, prompt response).

\section{Scales and Key Dimensions of E-service Quality}

In six of the articles studied, a scale for measuring e-service quality was developed (8.3\%). Dimensions identified in each scale are shown in Table 1.

With regard to dimensions identified in the e-service quality literature, various types of e-service quality dimensions were provided in the content analyzed research articles. Of the numerous dimensions, security/privacy was the most frequently indicated dimension $(f=32,44.4 \%)$. Security/ privacy was defined as the degree to which consumers' personal information is protected from the unauthorized use of disclosure and financial traction/information is secure (e.g., Evanschitzky et al., 2004; Parasuraman et al., 2005; Wolfinbarger \& Gilly, 2003).

Tied for second most frequently identified dimensions were responsiveness $(f=25,34.7 \%)$, reliability $(f=25,34.7 \%)$, and ease of use or usability $(f=25,34.7 \%)$. Responsiveness was defined as the extent to which a consumer's problems and inquiries are handled promptly (e.g., Lin, 2007; Nusair \& Kandampully, 2007). Reliability/fulfilment was related to performing promised service accurately in a timely manner and delivering accurate orders within the time frame promised (e.g., Sanayei et 
Table 1. e-service quality scales developed

\begin{tabular}{|c|c|}
\hline Author & Dimensions \\
\hline $\begin{array}{l}\text { Ding et al. (2011) } \\
\text { e-SELFQUAL }\end{array}$ & $\begin{array}{l}\text { Perceived control } \\
\text { Service convenience } \\
\text { Customer service } \\
\text { Service fulfillment }\end{array}$ \\
\hline $\begin{array}{l}\text { Herington and Weaven (2009) } \\
\text { E-ServQual }\end{array}$ & $\begin{array}{l}\text { Personal needs } \\
\text { Site organization } \\
\text { User-friendliness } \\
\text { Efficiency }\end{array}$ \\
\hline $\begin{array}{l}\text { Kim et al. (2006) } \\
\text { E-A-S-QUAL }\end{array}$ & $\begin{array}{l}\text { Efficiency } \\
\text { Fulfillment } \\
\text { System availability } \\
\text { Privacy } \\
\text { Responsiveness } \\
\text { Contact } \\
\text { Personalization } \\
\text { Information } \\
\text { Graphic style }\end{array}$ \\
\hline $\begin{array}{l}\text { Parasuraman et al. (2005) } \\
\text { E-S-QUAL/E-ReS-QUAL }\end{array}$ & $\begin{array}{l}\text { Efficiency } \\
\text { System availability } \\
\text { Fulfillment } \\
\text { Privacy } \\
\text { Responsiveness } \\
\text { Compensation } \\
\text { Contact }\end{array}$ \\
\hline $\begin{array}{l}\text { Rolland and Freeman (2010) } \\
\text { E-tail SQ }\end{array}$ & $\begin{array}{l}\text { Ease of use } \\
\text { Information content } \\
\text { Security/privacy } \\
\text { Fulfillment reliability } \\
\text { Post-purchase customer service }\end{array}$ \\
\hline $\begin{array}{l}\text { Wolfinbarger and Gilly (2003) } \\
\text { eTailQ }\end{array}$ & $\begin{array}{l}\text { Website design } \\
\text { Fulfillment/reliability } \\
\text { Privacy/security } \\
\text { Customer service }\end{array}$ \\
\hline
\end{tabular}

Table 2. Frequently examined dimensions and outcome variables

\begin{tabular}{|l|l|}
\hline \multicolumn{1}{|c|}{ Dimensions } & \multicolumn{1}{c|}{ Frequently examined outcome variables } \\
\hline Security/Privacy & e-satisfaction, e-loyalty, online trust, repurchase intention \\
\hline Responsiveness & e-satisfaction, e-loyalty, e-trust, repurchase intention \\
\hline Reliability/fulfilment & $\begin{array}{l}\text { e-satisfaction, e-loyalty, e-service quality, repurchase } \\
\text { intention }\end{array}$ \\
\hline Information quality and content & $\begin{array}{l}\text { ease of use, usefulness, e-satisfaction, e-service quality, } \\
\text { e-loyalty, repurchase intention, WOM }\end{array}$ \\
\hline Ease-of-use/Usability & e-satisfaction, e-trust, e-service quality \\
\hline Website design & $\begin{array}{l}\text { e-satisfaction, repurchase intention, e-service quality, } \\
\text { e-loyalty, WOM, }\end{array}$ \\
\hline System availability & e-service quality, e-satisfaction, e-loyalty, WOM \\
\hline
\end{tabular}


al., 2011; Wolfinbarger \& Gilly, 2003). Ease of use or usability was defined as the extent to which a website helps customers find what they need with ease (e.g., Al-Tarawneh, 2012; San et al., 2010).

Information content $(f=24,33.3 \%)$, graphic design $(f=18,25 \%)$, and system availability $(f=17$, $23.6 \%$ ) were also frequently identified as key elements of e-service quality. Personalization, e-trust, and contact were identified in a few studies. Of the various key dimensions identified, a dimension associated with the appearance of the website was the most noted dimension described using many different terms across the studies (e.g., appearance, atmospheric cues, e-aesthetic appeal, e-scape, website aesthetics, website design, etc.).

\section{Outcome Variables}

E-satisfaction was the most frequently considered outcome variable $(f=25,34.7 \%)$, followed by loyalty $(f=22,29.2 \%)$, and overall e-service quality $(f=17,23.6 \%)$. Perceived value $(f=8,11.11 \%)$ and word-of-mouth (WOM) $(f=8,11.11 \%)$ were also examined in several articles (see Table 2). A few studies examined perceived risk, and no studies examined actual purchasing behavior.

\section{Theory Used}

Approximately one-third of the studies applied a theory to elucidate the theoretical context of the study $(f=28,38.9 \%)$. The Technology Acceptance Model (TAM) (Davis, 1989; Moon \& Kim, 2001) and Information Success Model (DeLone \& McLean, 1992; 2003) were the most often applied theoretical frameworks $(f=5,6.9 \%$, respectively). The Stimulus-Organism-Response model (Eroglu, Machleit, \& Davis, 2001, 2003; Mehrabian \& Russell, 1974) was used in three studies, and Hofstede's (1980, 1991, 2001) cultural dimensions were also utilized in three cultural context studies.

\section{DISCUSSION}

E-service quality is a crucial factor in determining the success of e-retailers (Chen, Tsai, Hus, \& Lee, 2013). The current research thoroughly evaluated and synthesized e-service literature published during an 11 year period (January 2003 to December 2013) to develop a more clear understanding of 1) e-service definition, 2) e-service quality definition, 3) e-service quality scales, 4) key dimensions of e-service quality, 5) the most frequently studied outcome variables, and 6) the theories that have been utilized as conceptual frameworks.

The majority of the content analyzed articles contained no definition of e-service. The various definitions provided in the literature are fragmented and are primarily confined to one channel of service networking, mostly the Internet, with no clear definition of what services mean in the online context. Rowley defined e-service as "deeds, efforts or performances whose delivery is mediated by information technology (including the Web, information kiosks and mobile devices). Such e-service includes the service element of e-tailing, customer support and service, and service delivery" (p. 341). This definition is inclusive and seems to be relevant to the role of e-service in today's market. At present, e-service is not only limited to the Internet, rather it broadly covers other electronic networks. Therefore, the concept of e-service should be broad enough to cover all types of technologies used to access a retail website including tablets and smartphones.

Compared to the definition of e-service, the definition of e-service quality appears more often in the extant e-service research. Several definitions available in the literature are fairly in-depth enough to encompass the complete customer experience with a site. However, almost one third of the articles did not provide a definition of e-service quality. Furthermore, in several articles, researchers' definitions of e-service quality were quite limited and did not include all phases of e-service quality from prepurchase to post-purchase. How e-service quality is defined in a study is crucial since it relates to the key dimensions identified in the study. In essence, e-service quality should embrace all types of consumer interactions with and experiences through sites from the pre-purchase phase to the afterpurchase phase unless a researcher is only interested in e-service quality during a specific stage of 
purchase. For instance, O'Cass and Carlson's (2012a) definition of e-service quality is associated with consumer experience during the website encounter. Therefore, they focus on the website interactive quality such as information quality, functionality quality, and aesthetic consistency. Dimensions related to after-purchase phases were not considered in their study. In Parasuraman et al. (2005), e-service quality is related to the interaction phase as well as the after purchase phase. Thus, their definition of e-service quality reflects all phases and includes key dimensions embracing all phases from initial interaction to post-interaction features.

Few researchers developed a scale for the measurement of e-service quality. Instead, most of the articles in this analysis identified dimensions of e-service quality. With regards to the key dimensions of e-service quality, the most frequently examined dimensions were security/privacy, responsiveness, reliability/fulfillment, information content, and ease of use. Several studies provide no detailed explanation regarding dimensions and/or items used to measure the dimensions. In many cases, researchers developed a new name for an already well-developed dimension or used the same name but defined it in a different way. For example, website design in some articles is associated with design and graphic styles of website, site aesthetics, or appearance; however in others, it relates to ease of use, convenience, usability, and/or navigation capability. In a similar vein, studies which utilized the same theory as a framework defined key dimensions differently. For example, several articles examined consumers' perceptions of key dimensions based on DeLone and McLean's e-commerce success model which includes system quality, information quality, and service quality as determinants of e-service. In one article in the proposed research model security/privacy was included in system quality, but in other articles security/privacy was included in service quality or information quality. To resolve this inconsistency problem, researchers need to pay more attention to the dimensions developed in previous research and utilize the terms and items that are already well-defined. In addition, they need to provide clear definitions of each dimension identified. Attention to consistency will result in more clarity, less confusion, and less misinterpretation of dimension names by readers. Consistency will also make it easier for future researchers to build on past research.

In particular, the most frequently examined dimensions of e-service quality in the extant literature were utilitarian aspects such as security/privacy, responsiveness, reliability/fulfillment, information content, and ease of use. Hedonic aspects of e-service such as personalization and playfulness were identified in a few studies. Hedonic e-service quality elements are important factors that affect consumers' shopping outcomes (e.g., Ahn et al., 2007; Bauer et al., 2006; Bernardo, Marimon, \& Alonso-Almeida, 2012). According to Bernardo et al. (2012), the enjoyment of the shopping experience is just as important to e-consumers as purchasing goods, and hedonic quality is the factor that generates a competitive advantage by differentiating one website from another website. Hence, e-service researchers should broaden their view and encompass all aspects of the consumer shopping experience by including both functional and hedonic parts of e-service quality.

Concerning the outcome variables examined in the e-service quality literature, as predicted, e-satisfaction was the most investigated outcome variable followed by e-loyalty. There are quite a few variables that are affected by e-service quality, such as actual purchase behavior, attitude, perceived risk, and so forth. By employing different outcome variables, researchers can more comprehensively understand the impact of key dimensions of e-service quality on consumers' behavior.

Much of the research analyzed in the current study did not apply theory. Theories are useful for explaining and predicting research outcomes. A theory can be used as an overarching concept for explaining overall relationships among constructs, which can provide a clear and comprehensive view of the study as a whole. There are various applicable theories researchers can apply in the context of e-service quality research, such as TAM, theory of reasoned action, IS success model, S-O-R, and others. In order to provide a comprehensive view or explanation of a study's results, it is recommended that researchers conduct theory-based research. 


\section{CONCLUSION}

The current research content analyzed previous e-service quality research to provide a holistic evaluation of current extant literature and discover voids in the literature as a direction for future research. Definitions of e-service/e-service quality, e-service quality scales, key dimensions of e-service quality, outcome variables, and utilized theories were the foci of this study.

Notwithstanding the massive amount of research on e-service quality, the definitions of e-service/ e-service quality are not well-defined in the literature. Key dimensions of e-service quality should be understood based on a clear concept of e-service/e-service quality. Today the word "e-service" does not only refer to the Internet. With the up-to-date technology and wide-spread use of Wi-Fi, the boundary of the terminology is limitless. Furthermore, with the advent of omni-channel retailing, the boundary between a physical retailing and e-retailing is ambiguous.

In addition to the current technology, today e-service goes beyond the interactive exchange of information only. More and more consumers are highly involved with online websites through design customization or co-production of products. The hedonic aspect of services as well as functional aspects should be considered in definitions of e-service/e-service quality. Thus, when e-researchers define e-service, they should think through the technology-based revolution of the current business structure and the holistic aspects of e-service in today's business environment.

Compared to various dimensions of e-service quality examined in the literature, the outcome variables of e-service quality have received little attention from e-service quality researchers. Along with the inclusion of diverse dimensions of e-service quality in research, different outcome variables should be examined to better understand the crucial framework of e-service quality.

Unlike many other consumer behavior fields, there are few conceptual theories established to explain an e-service quality concept and structure. Even the few well-known theories have several drawbacks. One drawback includes multiple conceptualizations of the dimensions of e-service quality. Service quality researchers have also identified a lack of consideration of culture and context (Polyakova \& Mirza, 2015) in the theoretical formulations of service quality that may carry over to e-service quality. Thus, rather than developing new models, the field of e-service quality would be well-served if researchers used existing models and revamped them in different contexts and/or with different samples to develop a stable model through replication.

\section{REFERENCES}

Ahn, T., Ryu, S., \& Han, I. (2007). The impact of web quality and playfulness on user acceptance of online retailing. Information \& Management, 44(3), 263-275. doi:10.1016/j.im.2006.12.008

Akinci, S., Atilgan-Ina, E., \& Aksoy, S. (2010). Reassessment of E-S-Qual and E-RecS-QUAL in a pure service setting. Journal of Business Research, 63(3), 232-240. doi:10.1016/j.jbusres.2009.02.018

Al-Tarawneh, K. A. (2012). Measuring e-service quality from the customers' perspective: An empirical study on banking services. International Research Journal of Finance and Economics, 91, 123-137.

Bauer, H. H., Falk, T., \& Hammerschmidt, M. (2006). eTransQual: A transaction process-based approach for capturing service quality in online shopping. Journal of Business Research, 59(7), 866-875. doi:10.1016/j. jbusres.2006.01.021

Bernardo, M., Marimon, F., \& Alonso-Almeida, M. M. (2012). Functional quality and hedonic quality: A study of the dimensions of e-service quality in online travel agencies. Information \& Management, 49(7-8), 342-347. doi:10.1016/j.im.2012.06.005

Bernath, U., \& Vidal, M. (2007). The theories and the theorists: Why theory is important for research. Distances et saviors, 5(3), 427-458. 
Bressolles, G., Durrieu, F., \& Senecal, S. (2014). A consumer typology based on e-service quality and e-satisfaction. Journal of Retailing and Consumer Services, 21(6), 889-896. doi:10.1016/j.jretconser.2014.07.004

Carlson, J., \& O'Cass, A. (2011). Developing a framework for understanding e-service quality, its antecedents, consequences, and mediators. Managing Service Quality, 21(3), 264-286. doi:10.1108/09604521111127965

Cavanagh, S. (1997). Content analysis: Concepts, methods and applications. Nurse Researcher, 4, 5-16. PMID:27285770

Charlton, G. (2015). Ecommerce consumer reviews: Why you need them and how to use them. Econsultancy. Retrieved from https://econsultancy.com/blog/9366-ecommerce-consumer-reviews-why-you-need-them-andhow-to-use-them/

Chen, M.-H., Tsai, K.-M., Hsu, Y.-C., \& Lee, K.-Y. (2013). E-service quality impact on online customer's perceived value and loyalty. China-USA Business Review, 12(5), 473-485.

Creswell, J. W. (2014). Research design: Qualitative, quantitative, and mixed methods approaches (4th ed.). Thousand Oaks, California: SAGE Publications, Inc.

Cronin, J. J., \& Taylor, S. A. (1992). Measuring service quality: A reexamination and extention. Journal of Marketing, 56(3), 55-68. doi:10.2307/1252296

Davis, F. D. (1989). Perceived usefulness, perceived ease of use, and user acceptance of information technology. Management Information Systems Quarterly, 13(3), 319-340. doi:10.2307/249008

DeLone, W. H., \& McLean, E. R. (1992). Information systems success: The quest for the dependent variable. Information Systems Research, 3(1), 60-95. doi:10.1287/isre.3.1.60

DeLone, W. H., \& McLean, E. R. (2003). The DeLone and McLean model of information systems success: A ten-year update. Journal of Management Information Systems, 19(4), 9-30.

Elo, S., \& Kyngäs, H. (2007). The qualitative content analysis process. Journal of Advanced Nursing, 62(1), 107-115. doi:10.1111/j.1365-2648.2007.04569.x PMID:18352969

Eroglu, S. A., Machleit, K. A., \& Davis, L. M. (2001). Atmospheric qualities of online retailing: A conceptual model and implications. Journal of Business Research, 54(2), 177-184. doi:10.1016/S0148-2963(99)00087-9

Eroglu, S. A., Machleit, K. A., \& Davis, L. M. (2003). Empirical testing of a model of online store atmospherics and shopper responses. Psychology and Marketing, 20(2), 139-150. doi:10.1002/mar.10064

Evanschitzky, H., Iyer, G. R., Hesse, J., \& Ahlert, D. (2004). E-satisfaction: A re-examination. Journal of Retailing, 80(3), 239-247. doi:10.1016/j.jretai.2004.08.002

Grönroos, C. (1984). A service quality model and its marketing implications. European Journal of Marketing, 18(4), 36-44. doi:10.1108/EUM0000000004784

Hofstede, G. (1980). Culture consequences: International differences in work-related values. Beverly Hills, CA: Sage.

Hofstede, G. (1991). Culture and organization: Software of the mind. London: McGraw-Hill.

Hofstede, G. (2001). Cultures consequences (2nd ed.). Thousand Oaks, CA: Sage Publications.

Hsieh, H.-F., \& Shannon, S. E. (2005). Three approaches to qualitative content analysis. Qualitative Health Research, 15(9), 1277-1288. doi:10.1177/1049732305276687 PMID:16204405

Kerlinger, F. N. (1979). Behavioral research: A conceptual approach. New York: Holt, Rinehart \& Winston.

Kim, J.-H., \& Kim, C. (2010). E-service quality perceptions: A cross-cultural comparison of American and Korean consumers. Journal of Research in Interactive Marketing, 4(3), 257-275. doi:10.1108/17505931011070604

Kim, J.-H., Kim, M., \& Kandampully, J. (2007). The impact of buying environment characteristics of retail websites. Service Industries Journal, 27(7), 865-880. doi:10.1080/02642060701570529

Kim, J.-H., \& Lennon, S. J. (2012). Electronic retailing and service quality. In J. Kandampully (Ed.), Services management: The new paradigm in retailing. New York, NY: Springer. doi:10.1007/978-1-4614-1554-1_7 
Kim, M., Kim, J.-H., \& Lennon, S. J. (2006). Online service attributes available on apparel retail web sites: An E-S-QUAL approach. Managing Service Quality, 16(1), 51-77. doi:10.1108/09604520610639964

Ladhari, R. (2010). Developing e-service quality scales: A literature review. Journal of Retailing and Consumer Services, 17(6), 464-477. doi:10.1016/j.jretconser.2010.06.003

Lin, H.-F. (2007). The impact of website quality dimensions on customer satisfaction in the B2C e-commerce context. Total Quality Management, 18(4), 363-378. doi:10.1080/14783360701231302

Lin, H.-H. (2012). The effect of multi-channel service quality on mobile customer loyalty in an online-and-mobile retail context. Service Industries Journal, 32(11), 1865-1882. doi:10.1080/02642069.2011.559541

Mehrabian, A. \& Russell, J.A. (1974). An approach to environmental psychology. Cambridge, MA: MIT Press.

Moon, J.-M., \& Kim, Y.-G. (2001). Extending the TAM for a World-Wide-Web context. Information \& Management, 38(4), 217-230. doi:10.1016/S0378-7206(00)00061-6

National Retail Federation. (n. d.). Retail insight center. Retrieved from http://research.nrffoundation.com/ Default.aspx?pg=46\#.VcOJd_lVhBc

Nusair, K., \& Kandampully, J. (2008). The antecedents of customer satisfaction with online travel services: A conceptual model. European Business Review, 20(1), 4-19. doi:10.1108/09555340810843663

O'Cass, A., \& Carlson, J. (2012a). An empirical assessment of consumers' evaluations of web site service quality: Conceptualizing and testing a formative model. Journal of Services Marketing, 26(6), 419-434. doi:10.1108/08876041211257909

Parasuraman, A., Zeithaml, V. A., \& Berry, L. L. (1985). A conceptual model of services quality and its implication for future research. Journal of Marketing, 49(4), 41-50. doi:10.2307/1251430

Parasuraman, A., Zeithaml, V.A., \& Berry, L.L. (1988). Servqual: A multiple-item scale for measuring consumer perceptions of service quality. Journal of Retailing, 64(1), 12-40.

Parasuraman, A., Zeithaml, V. A., \& Malhotra, A. (2005). E-S-QUAL: A multiple-item scale for assessing electronic service quality. Journal of Service Research, 7(3), 213-233. doi:10.1177/1094670504271156

Polyakova, O., \& Mirza, M. (2015). Perceived service quality models: Are they still relevant? The Marketing Review, 15(1), 59-82. doi:10.1362/146934715X14267608178721

Poon, W., \& Lee, C. (2012). E-Service Quality: An Empirical Investigation. Journal of Asia-Pacific Business, 13(3), 229-262. doi:10.1080/10599231.2012.690682

Potter, W. J., \& Levine-Donnerstein, D. (1999). Rethinking validity and reliability in content analysis. Journal of Applied Communication Research, 27(3), 258-284. doi:10.1080/00909889909365539

Rafiq, M., Lu, X., \& Fulford, H. (2012). Measuring Internet retail service quality using E-S-QUAL. Journal of Marketing Management, 28(9-10), 1159-1173. doi:10.1080/0267257X.2011.621441

Retailing Today. (2013). Study: 81\% research online before making big purchases. Retrieved from http://www. retailingtoday.com/article/study-81-research-online-making-big-purchases

Rolland, S., \& Freeman, I. (2010). A new measure of e-service quality in France. International Journal of Retail \& Distribution Management, 38(7), 497-517. doi:10.1108/09590551011052106

Rowley, J. (2006). An analysis of the e-service literature: Towards a research agenda. Internet Research, 16(3), 339-359. doi:10.1108/10662240610673736

Rust, R. T. (2001). The rise of e-service. Journal of Service Research, 3(5), 283-284. doi:10.1177/109467050134001

Rust, R.T., \& Lemon, K.N. (2001). E-service and the consumer. International Journal of Electronic Commerce, $5(3), 85-101$.

Sabiote, C., Frías, D., \& Castañeda, J. (2012). E-service quality as antecedent to e-satisfaction: The moderating effect of culture. Online Information Review, 36(2), 157-174. doi:10.1108/14684521211229011 
San, L.Y., Jun, W.W., Ling, T.N., \& Hock, N.T. (2010). Customers' perceived online shopping service quality: The perspective of generation Y. European Journal of Economics. Finance and Administrative Sciences, 25, 83-93.

Sanayei, A., Shaemi, A., \& Nasirzadeh, M. (2011). E-service quality, e-satisfaction and e-loyalty from the view of Iranian users. Interdisciplinary Journal of Contemporary Research in Business, 3(6), 807-815.

Santos, J. (2003). E-service quality: A model of virtual service quality dimensions. Managing Service Quality: An International Journal, 13(3), 233-246. doi:10.1108/09604520310476490

Swaid, S.I., \& Wigand, R.T. (2012). The Effect of Perceived Site-to-Store Service Quality on Perceived Value and Loyalty Intentions in Multichannel Retailing. International Journal of Management, 29(3), 301-313.

Thaichon, P., Lobo, A., Prentice, C., \& Quach, T. N. (2014). The development of service quality dimensions for Internet service providers: Retailing customers of different usage patterns. Journal of Retailing and Consumer Services, 21(6), 1047-1058. doi:10.1016/j.jretconser.2014.06.006

Toufaily, E., Ricard, L., \& Perrien, J. (2013). Customer loyalty to a commercial website: Descriptive metaanalysis of the empirical literature and proposal of an integrative model. Journal of Business Research, 66(9), 1463-1447. doi:10.1016/j.jbusres.2012.05.011

Trabold, L. M., Heim, G. R., \& Field, J. M. (2006). Comparing e-service performance across industry sectors: Drivers of overall satisfaction in online retailing. International Journal of Retail \& Distribution Management, 34(4/5), 240-257. doi:10.1108/09590550610660215

Tsang, N. K. F., Lai, M. T. H., \& Law, R. (2010). Measuring e-service quality for online travel agencies. Journal of Travel \& Tourism Marketing, 27(3), 306-323. doi:10.1080/10548401003744743

Tsao, W.-C., \& Tseng, Y.-L. (2011). The impact of electronic-service quality on online shopping behavior. Total Quality Management, 22(9), 1007-1024. doi:10.1080/14783363.2011.593869

Van Vliet, P.J.A., \& Pota, D. (2001). Understanding online retail: A classification of online retailers. Journal of Computer Information Systems, 41(2), 23-28.

Vila, N., \& Kuster, I. (2011). Consumer feelings and behaviors towards well designed websites. Information \& Management, 48(4-5), 166-177. doi:10.1016/j.im.2011.04.003

Wacker, J. G. (1998). A definition of theory: Research guidelines for different theory-building research methods in operations management. Journal of Operations Management, 16(4), 361-385. doi:10.1016/S02726963(98)00019-9

Wolfinbarger, M., \& Gilly, M. (2003). eTailQ: Dimensionalizing, measuring, and predicting retail quality. Journal of Retailing, 79(3), 183-193. doi:10.1016/S0022-4359(03)00034-4

Yaya, L. H. P., Marimon, F., \& Fa, M. C. (2012). Assessing e-service quality: The current state of E-S-QUAL. Total Quality Management \& Business Excellence, 23(11-12), 1363-1378. doi:10.1080/14783363.2012.728850

Yoo, B., \& Donthu, N. (2001). Developing a scale to measure perceived quality of an Internet shopping site (SITEQUAL). International Journal of Service Industry Management, 14(5), 483-500.

Zaibaf, M., Taherikia, F., \& Fakharian, M. (2013). Effect of perceived service quality on customer satisfaction in hospitality industry: Gronroos's service quality model development. Journal of Hospital Marketing, 22(5), 490-504. doi:10.1080/19368623.2012.670893

Zeithaml, V.A., Parasuraman, A., \& Malhotra, A. (2000). A conceptual framework for understanding e-service quality: Implications for future research and managerial practice (Working Paper, Report No. 00-115). Marketing Science Institute, Cambridge, MA.

Zeithaml, V. A., Parasuraman, A., \& Malhotra, A. (2002). Service quality delivery through web sites: A critical review of extant knowledge. Journal of the Academy of Marketing Science, 30(4), 358-371. doi:10.1177/009207002236911

Zhao, Y. L., \& Di Benedetto, C. A. (2013). Designing service quality to survive: Empirical evidence from Chinese new ventures. Journal of Business Research, 66(8), 1098-1107. doi:10.1016/j.jbusres.2012.03.006 
Jung-Hwan Kim is an Associate Professor in the Department of Retailing at University of South Carolina. She has held her professional position in retailing management for over 11 years. Her current research interests include e-retailing service quality, consumer shopping behaviors its impact on decision-making process, and digital commerce.

Sharron J. Lennon is Professor in the Department of Apparel Merchandising and Interior Design at Indiana University-Bloomington. She studies dress from a social/psychological perspective and teaches graduate and undergraduate courses in consumer behavior and dress. She has published numerous refereed research articles and book chapters. Her current research interests include customer service, online consumer behavior, and consumer misbehavior on Black Friday. 